\title{
ANALIZA SKLADU WYBRANYCH BUTELKOWANYCH WÓD MINERALNYCH WYSTĘPUJĄCYCH NA RYNKU EUROPEJSKIM
}

\begin{abstract}
W pracy dokonano charakterystyki składu wybranych butelkowanych wód mineralnych występujących na rynku europejskim. Analizą objęto 1030 wód mineralnych, w tym z Niemiec (9,4\% ogólnego udziału), Hiszpanii (9,5\%), Włoch $(9,2 \%)$, Francji $(9,2 \%)$, pozostałe $62,6 \%$ stanowią inne państwa. Dokonano klasyfikacji analizowanych wód według obowiązujących aktów prawnych. Przedstawiono również charakterystykę 23 wód mineralnych według największej zawartości danego minerału oraz hierarchizację porządkowania liniowego, uwzględniająca kombinację wszystkich składników mineralnych.
\end{abstract}

Słowa kluczowe: butelkowane wody mineralne, skład chemiczny, Europa

\section{Wprowadzenie}

Jak szacuje instytut badawczy Euromonitor International, tempo zużycia wody mineralnej w Europie w przyszłości będzie się zwiększać. Według szacunków do największych producentów wody mineralnej w Europie należą (według rocznej produkcji) [1]:

- Niemcy - 12,87 mld dm ${ }^{3}$,

- Włochy - 12,35 mld $\mathrm{dm}^{3}$,

- Francja - 7,5 mld dm ${ }^{3}$,

- Hiszpania - 6,1 mld $\mathrm{dm}^{3}$,

- Polska - 2,35 mld dm ${ }^{3}$,

- Wielka Brytania - 1,5 mld $\mathrm{dm}^{3}$.

Produkcja wody mineralnej na jednego mieszkańca w Europie (przy średniej równej 105,6 $\mathrm{dm}^{3} \cdot \mathrm{Mk}$ ) kształtuje się następująco [1]:

- Polska $-61,9 \mathrm{dm}^{3} \cdot \mathrm{Mk}^{-1}$,

- Rumunia - 63,3 $\mathrm{dm}^{3} \cdot \mathrm{Mk}^{-1}$,

- Austria $-96,5 \mathrm{dm}^{3} \cdot \mathrm{Mk}^{-1}$,

- Węgry - 102,2 $\mathrm{dm}^{3} \cdot \mathrm{Mk}^{-1}$,

- Francja-121,9 $\mathrm{dm}^{3} \cdot \mathrm{Mk}^{-1}$, 
- Hiszpania $-136,5 \mathrm{dm}^{3} \cdot \mathrm{Mk}^{-1}$,

- Niemcy $-155,9 \mathrm{dm}^{3} \cdot \mathrm{Mk}^{-1}$,

- Włochy $-198,0 \mathrm{dm}^{3} \cdot \mathrm{Mk}^{-1}$.

Głównymi czynnikami wpływającymi na decyzję zakupu wody mineralnej są smak i przyzwyczajenia konsumenta oraz estetyka opakowania. Mniejsze znaczenie mają cena, zapach i informacje zawarte na opakowaniu. Najmniej istotne w wyborze wody mineralnej są reklama i nowości na rynku wód butelkowanych [2].

Do podstawowych składników wód mineralnych, których zawartość w wodzie decyduje o jej stopniu mineralizacji, należą: aniony (chlorkowy, wodorowęglanowy i siarczanowy) oraz kationy (sodowy, potasowy, wapniowy i magnezowy).

Minimalne stężenia niektórych składników wód mineralnych, które mają znaczenie fizjologiczno-odżywcze, przedstawiają się następująco: wapń $\geq 150$ $\mathrm{mg} \cdot \mathrm{dm}^{-3}$, magnez $\geq 50 \mathrm{mg} \cdot \mathrm{dm}^{-3}$, sód $\geq 200 \mathrm{mg} \cdot \mathrm{dm}^{-3}$, chlorki $\geq 200 \mathrm{mg} \cdot \mathrm{dm}^{-3}$, siarczany $\geq 200 \mathrm{mg} \cdot \mathrm{dm}^{-3}$, wodorowęglany $\geq 600 \mathrm{mg} \cdot \mathrm{dm}^{-3}$. Znaczenie dietetyczne ma sód o wartości $\geq 20 \mathrm{mg} \cdot \mathrm{dm}^{-3}$ [3]. Jeżeli chodzi o aspekt zdrowotny wybranych składników mineralnych, to przedstawia się on następująco $[4,5]$ :

1. Wapń to główny składnik budulcowy kości i zębów. Odpowiada za pobudliwość układu nerwowo-mięśniowego, opóźnia występowanie zmęczenia mięśni. Ma wpływ na prawidłową czynność serca i decyduje o prawidłowym krzepnięciu krwi. Dobowe zapotrzebowanie na wapń organizmu człowieka wynosi od 800 do $1200 \mathrm{mg}$.

2. Magnez odgrywa ważną rolę w profilaktyce i terapii wielu chorób. Działa przeciwstresowo, przeciwalergicznie i przeciwtoksycznie (dobowe zapotrzebowanie od 300 do $600 \mathrm{mg}$ ). Uczestniczy w aktywnym transporcie potasu i sodu. Niedobory magnezu powodują zaburzenia układu krążenia i nadpobudliwość układu nerwowego.

3. Potas to podstawowy składnik cieczy wewnątrzkomórkowej odpowiedzialny za regulowanie odczynu pH i ciśnienia osmotycznego w komórkach.

4. Sód to główny składnik cieczy pozakomórkowych (osocze krwi). Niedobór tego jonu powoduje przyśpieszone odwodnienie organizmu. Zaburzenia równowagi sodowo-chlorowo-potasowej prowadzą do zachwiania równowagi kwasowo-zasadowej (zakwaszenie organizmu).

Według Dyrektywy Parlamentu Europejskiego i Rady 2009/54/WE z dnia 18 czerwca 2009 r. w sprawie wydobywania i wprowadzania do obrotu naturalnych wód mineralnych oraz Dyrektywy 2001/83/WE Parlamentu Europejskiego i Rady z dnia 6 listopada 2001 r. w sprawie wspólnotowego kodeksu odnoszącego się do produktów leczniczych stosowanych u ludzi, naturalna woda mineralna oznacza wodę podziemną wydobywaną jednym lub kilkoma otworami naturalnymi lub wierconymi, różniącą się od wody przeznaczonej do spożycia przez 
ludzi pierwotną czystością pod względem chemicznym i mikrobiologicznym oraz charakterystycznym stabilnym składem mineralnym, a w określonych przypadkach także właściwościami mającymi znaczenie fizjologiczne, powodującymi korzystne oddziaływanie na zdrowie ludzi [6].

Klasyfikacja naturalnych wód mineralnych w zależności od ogólnej zawartość soli mineralnych według Dyrektywy 2009/54/WE przedstawia się następująco [7]:

- bardzo niskozmineralizowana - mniej niż $50 \mathrm{mg} \cdot \mathrm{dm}^{-3}$,

- niskozmineralizowana - mniej niż $500 \mathrm{mg} \cdot \mathrm{dm}^{-3}$,

- średniozmineralizowana - mniej niż $1500 \mathrm{mg} \cdot \mathrm{dm}^{-3}$,

- wysokozmineralizowana - powyżej $1500 \mathrm{mg} \cdot \mathrm{dm}^{-3}$.

W artykule 9 ust. 2 Dyrektywy 2009/54/WE ustanowiono także inne oznaczenia i kryteria [7]:

- zawiera wodorowęglany - zawartość wodorowęglanów jest wyższa od $600 \mathrm{mg} \cdot \mathrm{dm}^{-3}$,

- zawiera siarczany - zawartość siarczanów jest wyższa od $200 \mathrm{mg} \cdot \mathrm{dm}^{-3}$,

- zawiera chlorki - zawartość chlorków jest wyższa od $200 \mathrm{mg} \cdot \mathrm{dm}^{-3}$,

- zawiera wapń - zawartość wapnia jest wyższa od $150 \mathrm{mg} \cdot \mathrm{dm}^{-3}$,

- zawiera magnez - zawartość magnezu jest wyższa od $50 \mathrm{mg} \cdot \mathrm{dm}^{-3}$,

- zawiera fluorki - zawartość fluorków jest wyższa od $1 \mathrm{mg} \cdot \mathrm{dm}^{-3}$,

- zawiera żelazo - zawartość żelaza dwuwartościowego jest wyższa od $1 \mathrm{mg} \cdot \mathrm{dm}^{-3}$,

- kwaśna - zawartość dwutlenku węgla jest wyższa od $250 \mathrm{mg} \cdot \mathrm{dm}^{-3}$,

- zawiera sód - zawartość sodu jest wyższa od $200 \mathrm{mg} \cdot \mathrm{dm}^{-3}$,

- odpowiednia dla diety ubogiej w sód - zawartość sodu jest niższa od $20 \mathrm{mg} \cdot \mathrm{dm}^{-3}$.

\section{Cel i zakres pracy}

W pracy przedstawiono analizę składu wybranych butelkowanych wód mineralnych i źródlanych występujących na rynku europejskim. Analizie poddano 1030 wód mineralnych, w tym z Niemiec (9,4\% ogólnego udziału), Hiszpanii $(9,5 \%)$, Włoch $(9,2 \%)$, Francji $(9,2 \%)$, pozostałe $62,6 \%$ stanowią inne państwa. Dokonano klasyfikacji analizowanych wód według obowiązujących aktów prawnych. Przedstawiono również charakterystykę 23 wód mineralnych według największej zawartości danego minerału oraz hierarchizację porządkowania liniowego, uwzględniając kombinację wszystkich składników mineralnych. 


\section{Analiza wyników badań}

W analizie uwzględniono państwa europejskie, z wyłączeniem krajów, których terytoria przekraczaja granice Europy (rys. 1.).

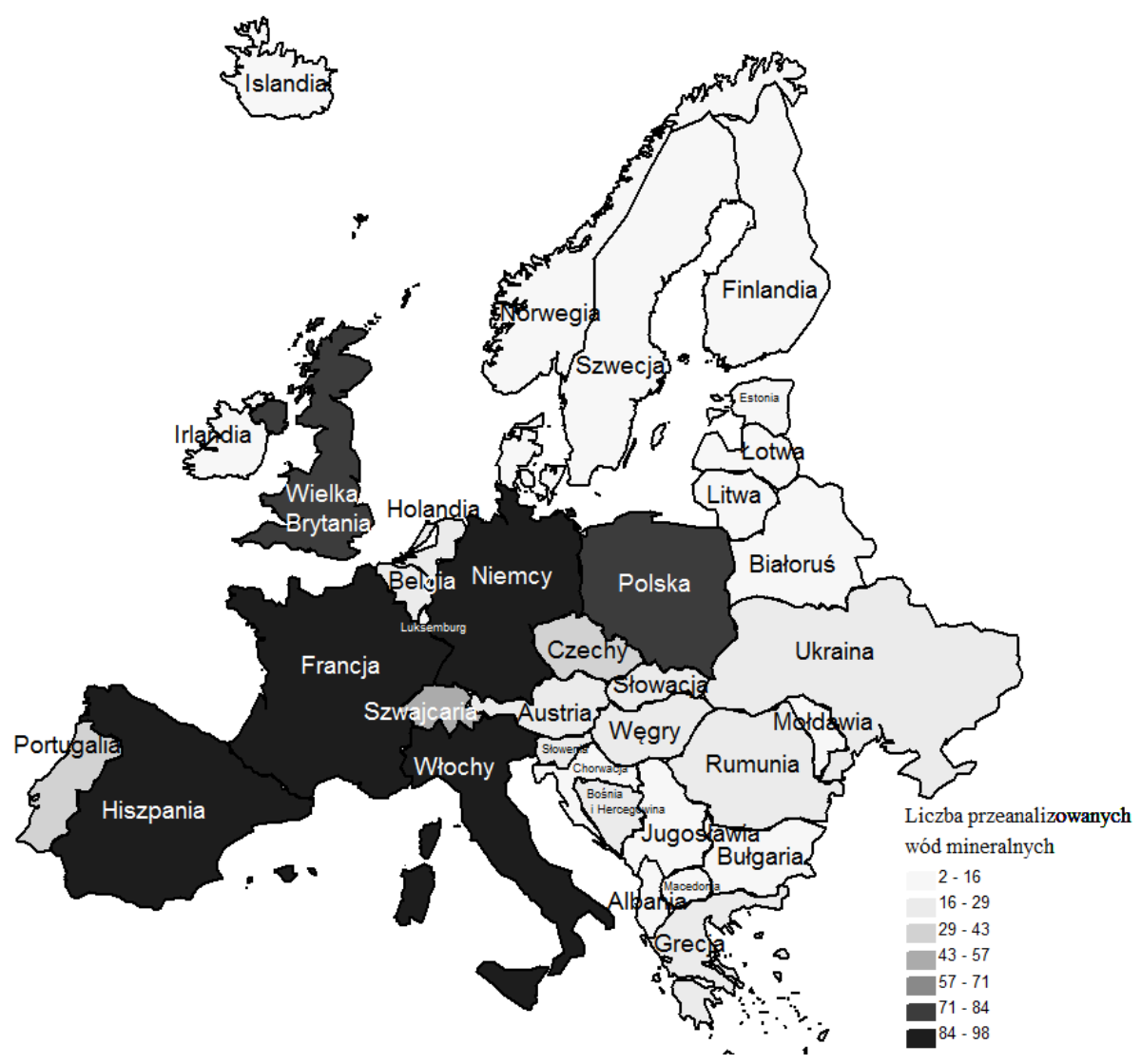

Rys. 1. Rozkład przeanalizowanych wód mineralnych

Spośród 1030 przeanalizowanych wód $11,63 \%$ stanowią wody bardzo niskozmineralizowane, $59,73 \%$ - wody niskozmineralizowane, $17,25 \%$ - wody średniozmineralizowane, a $11,75 \%$ - wody wysokozmineralizowane (według klasyfikacji podanej w Dyrektywie 2009/54/WE [7]). Około 16,2\% to wody o zawartości wodorowęglanów wyższej od $600 \mathrm{mg} \cdot \mathrm{dm}^{-3}$, ok. $13,2 \%$ - wody zawierające siarczany $\left(>200 \mathrm{mg} \cdot \mathrm{dm}^{-3}\right)$, ok. $7,7 \%$ - wody chlorkowe, ok. $16,0 \%$ - wody zawierające wapń, ok. $14,5 \%$ - wody zawierające magnez, ok. 13,3\% - wody fluorkowe, ok. 16,4\% - wody zawierające żelazo, 13,1\% - wody zawierające sód, ok. 53,1\% - wody odpowiednie dla diety ubogiej w sód (rys. 2.). 
Zawartość wodorowęglanów $\left[\mathrm{mg} \cdot \mathrm{dm}^{-3}\right]$

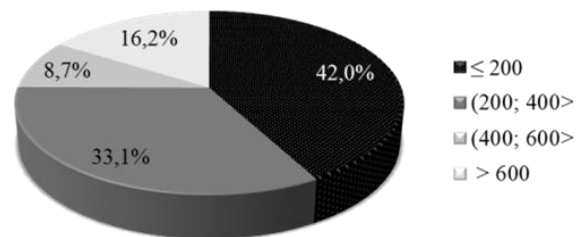

Zawartość chlorków $\left[\mathrm{mg} \cdot \mathrm{dm}^{-3}\right]$

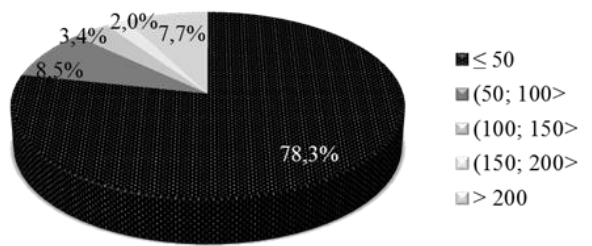

Zawartość magnezu $\left[\mathrm{mg} \cdot \mathrm{dm}^{-3}\right]$

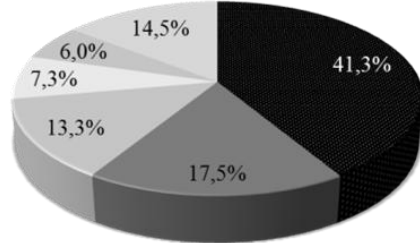

Zawartość fluorków $\left[\mathrm{mg} \cdot \mathrm{dm}^{-3}\right]$

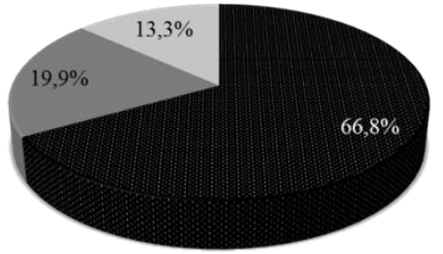

$\square(0,5 ; 1>$

$\square>1$
Zawartość siarczanów $\left[\mathrm{mg} \cdot \mathrm{dm}^{-3}\right]$

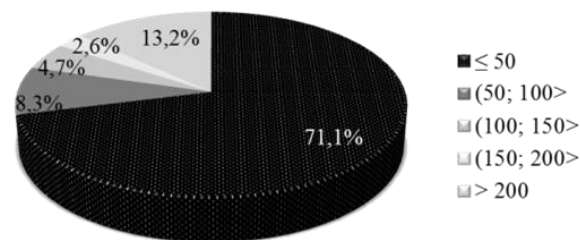

Zawartość wapnia $\left[\mathrm{mg} \cdot \mathrm{dm}^{-3}\right]$

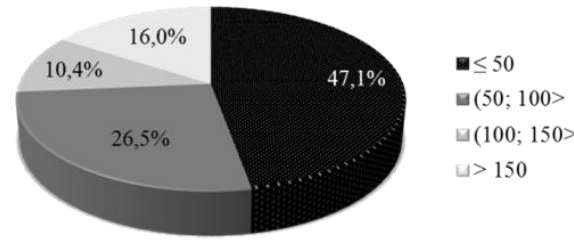

Zawartość sodu $\left[\mathrm{mg} \cdot \mathrm{dm}^{-3}\right]$

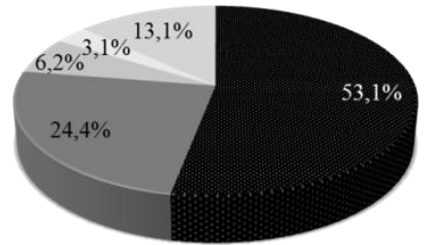

$<20$

몬 $(20 ; 80>$

$\square(80 ; 140>$

$\square(140 ; 200>$

$\square>200$

Zawartość żelaza dwuwartościowego $\left[\mathrm{mg} \cdot \mathrm{dm}^{-3}\right]$

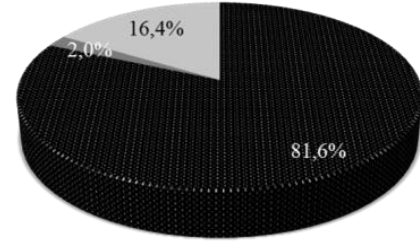

$\mathbf{m} \leq 0,5$

$\because(0,5 ; 1>$

Rys. 2. Klasyfikacja wód butelkowanych dostępnych na rynku europejskim

\section{Ranking wód mineralnych pod względem zawartości} wybranych kationów oraz anionów

Ranking wód pod względem zawartości magnezu $\left[\mathrm{mg} \cdot \mathrm{dm}^{-3}\right]$ :

1. Mira (Węgry)

- 496,

2. Karlsquelle Heilwasser (Niemcy)

- $\quad 389$,

3. Vulkania Heilwasser (Niemcy)

$-\quad 380,9$,

4. Bad Mergentheimer Karlsquelle (Niemcy) - 376,

5. Sulinka (Słowacja)

6. Nürburgquelle (Niemcy)

7. Valcele (Rumunia)

- 344,3,

8. Zuber (Polska)

9. San Lorenzo (Włochy)
- $\quad 337$,

- 335,61,

- 331,32,

- $\quad 315$, 
10. Aguas Verdes (Hiszpania)

256 ,

11. Vytautas (Litwa) - 254,

12. Miers (Francja) - 253,

13. Helenen Quelle Heilwasser (Niemcy) _ - 244,

14. Hydroxydase (Francja) - 243,

15. Dreiser Sprudel (Niemcy) - 241,

16. Bad Wildunger Helenenquelle (Niemcy) - 239,

17. Aqua Antonia (Czechy) - 236,3,

18. Long Life (Austria) - 206,

19. Lubovnianka (Słowacja) - 204,6,

20. Dauner (Niemcy) - 198,

21. Heppinger Extra (Niemcy) - 196,

22. Pandur Heilwasser (Niemcy) - 191,5,

23. Salvator (Słowacja) $\quad-\quad 177,6$.

Ranking wód pod względem zawartości wapnia $\left[\mathrm{mg} \cdot \mathrm{dm}^{-3}\right]$ :

1. Fonte del Faro (Włochy) - 1134,8,

2. Bad Mergentheimer Albertquelle (Niemcy) - 794,

3. Karlsquelle Heilwasser (Niemcy) - 782,

4. Bad Mergentheimer Karlsquelle (Niemcy) - 750,

5. Aqua Sara (Rumunia) - 715,8,

6. Acqua Santa di Chianciano (Włochy) - 714,

7. Acqua Arve (Włochy) - 694,

8. Pergoli di Tabiano (Włochy) - 680,

9. Aguas de Manzanera (Hiszpania) - 672,

10. Acqua Regina (Włochy) - 657,3,

11. Agua de Salenys (Hiszpania) - 651,

12. Wilhelmsquelle Heilwasser (Niemcy) _ - 645,

13. San Bernardino (Szwajcaria) - 638,9,

14. Sorgente Aurora (Włochy) - 632,

15. Rangauer life Heilwasser (Niemcy) - $\quad$ 620,

16. Acqua Fucoli (Włochy) - 615,

17. Obernauer Säuerling (Niemcy) - 613,

18. Obernauer Vital (Niemcy) - 613,

19. Quellq-Pur (Niemcy) - 613,

20. Filipoquelle Haigerloch (Niemcy) - 604 ,

21. Oberanuer Exclusiv (Niemcy) - 601,

22. Obernauer Löwen-Sprudel (Niemcy) - $\quad 601$,

23. Römer (Niemcy) - 601.

Ranking wód pod względem zawartości potasu $\left[\mathrm{mg} \cdot \mathrm{dm}^{-3}\right]$ :

1. Zuber (Polska) - 320,

2. Vesuvio (Włochy) - 300, 
3. Bad Mergentheimer Albertquelle (Niemcy) - 268,

4. San Paolo (Włochy) - 254,

5. San Ciro (Włochy) - 205,4,

6. Hydroxydase (Francja) - 192,2,

7. Cool Blue (Niemcy) - 181,

8. Vincentka (Czechy) - 166,

9. AquaLife (Mołdawia) - 152,

10. Tovtri (Ukraina) - 150,

11. Aqua Vita (Macedonia) - 148 ,

12. Laurentina (Włochy) $\quad-142,5$,

13. Cigelka (Słowacja) - 137,

14. Arvie (Francja) - 130,

15. Acqua Regina (Włochy) - 129,5,

16. Fontfort (Francja) - 120,

17. Toka (Włochy) - 115,5,

18. St. Yorre (Francja) - 115,

19. Karlsquelle Heilwasser (Niemcy) - 113,

20. Parot (Francja) - 110,

21. Toka (Włochy) $\quad-107,5$,

22. Oleska (Ukraina) - 107 ,

23. Vichy Classique (Litwa) - 100.

Ranking wód pod względem zawartości sodu $\left[\mathrm{mg} \cdot \mathrm{dm}^{-3}\right]$ :

1. Cigelka (Słowacja) $\quad-8127,9$,

2. Zuber (Polska) - 6495,

3. Acqua Regina (Włochy) - 5570,

4. Mira (Wegry) - 4800,

5. Karlsquelle Heilwasser (Niemcy) - 4795,

6. Kissinger Bitterwasser Heilwasser (Niemcy) - 4690,

7. Hunyadi Janos (Węgry) - 4680,

8. Bad Mergentheimer Karlsquelle (Niemcy) - 4670,

9. Pandur Heilwasser (Niemcy) - 2815,

10. Aguas Verdes (Hiszpania) - 2720,

11. Aguas de Manzanera (Hiszpania) - 2690,

12. Acqua Tettuccio (Włochy) - 2622,

13. Poljana (Ukraina) - 2500 ,

14. Saratica (Czechy) - 2203,

15. Maxbrunnen Heilwasser (Niemcy) - 2150,

16. Vincentka (Czechy) - 2017,

17. Hydroxydase (Francja) - 1945,

18. Bilinska Kyselka (Czechy) - 1802,

19. St. Yorre (Francja) - 1708,

20. Mlynsky (Czechy) - 1682, 
$\begin{array}{llll}\text { 21. Vytautas (Litwa) } & - & 1600, \\ \text { 22. Donat Mg (Słowacja) } & - & 1570, \\ \text { 23. Kaiser Friedrich Heilquelle (Niemcy) } & - & 1390 .\end{array}$

Ranking wód pod względem zawartości wodorowęglanów $\left[\mathrm{mg} \cdot \mathrm{dm}^{-3}\right]$ :

1. Cigelka (Słowacja) - 216461,1,

2. Zuber (Polska) - 18549,47,

3. Donat (Słowacja) - 7790,

4. Hydroxydase (Francja) - 6722,2,

5. Rogaska-Quell Heilwasser (Słowacja) - $\quad 6605$,

6. Poljana (Ukraina) - 6250,

7. Poljana Kvasova (Ukraina) $\quad$ - 5750,

8. Sulinka (Słowacja) - 5555,

9. Bilinska Kyselka (Czechy) - 4491,

10. St. Yorre (Francja) - 4368,

11. Svaliava (Ukraina) $\quad-\quad 4234$,

12. Vincentka (Czechy) - 3989,4,

13. Fontfort (Francja) - 3800,

14. Vulkania Heilwasser (Niemcy) - 3754,

15. Tuzlanski Kiseljak (Bośnia i Hercegowina) - 3706,

16. Dorna (Rumunia) - 3500,

17. Parot (Francja) - 3483,

18. Aqua Pannonia (Austria) - 3420,

19. Gleichenberger Johannisbrunnen (Austria) - $\quad 3420$,

20. Vitinka (Bośnia i Hercegowina) - 3415,

21. Nürburgquelle (Niemcy) - 3388,

22. Dauner (Niemcy) - 3363,

23. San Leopoldo (Włochy) - 3245,2,

Ranking wód pod względem zawartości chlorków $\left[\mathrm{mg} \cdot \mathrm{dm}^{-3}\right]$ :

1. Cigelka (Słowacja) - 3761,

2. Kissinger Bitterwasser Heilwasser (Niemcy) - 3739,

3. Vytautas (Litwa) $\quad-\quad 3437$,

4. Maxbrunnen Heilwasser (Niemcy) - 3328,

5. Mira (Węgry) - 2700,

6. Agua de Carabaña (Hiszpania) - 2493,

7. Soroco (Mołdawia) - 2211,6,

8. Birute (Litwa) - 2100,

9. Collalli (Włochy) - 1851 ,

10. Druskininku Rita (Litwa) - 1543,

11. Aachener Kaiserbrunnen (Niemcy) - 1486,

12. Darida (Białoruś) - 1478,

13. Kuyalnick (Ukraina) - 1435, 
14. Mirgorodska (Ukraina)

15. Valmieras Nr. 2 (Łotwa)

16. Druskininku Rasa (Litwa)

17. Kaiser Friedrich Heil-Quelle-N (Niemcy)

18. Bad Zwestener Löwensprudel Heilwasser (Niemcy)

19. Soluky (Ukraina)

20. Teberda (Ukraina)

21. Kuyalnick New (Ukraina)

22. San Pancrazio (Włochy)

23. St. Antonius Heilwasser (Niemcy)
1400 ,

$-\quad 1324$,

$-\quad 1235$,

- 916,

- 910,

- $\quad 907$,

- 905 ,

-
$-\quad 899$,

- 859,3,

$-\quad 808$

\section{Ranking wód mineralnych występujących na rynku europejskim}

W celu przeprowadzenia procedury klasyfikacji wód mineralnych z uwzględnieniem ich składu zastosowano klasyfikację liniową polegającą na wyznaczeniu miernika syntetycznego, będącego średnią wartości zmiennych składowych, według którego uporządkowano wody mineralne [8]. Przed przystapieniem do analizy dokonano unitaryzacji zmiennych ze względu na skalę wartości minerałów, korzystając ze wzoru:

$$
z_{i}=\frac{x_{i}-x_{\min }}{x_{\max }-x_{\min }}
$$

gdzie: $z_{i}-$ wartość atrybutu dla $i$-tego obiektu po unitaryzacji,

$x_{\min }-$ wartość minimalna, jaką przyjmuje dany atrybut w zbiorze badanych obiektów,

$x_{\max }-$ wartość maksymalna, jaką przyjmuje dany atrybut w zbiorze badanych obiektów,

$x_{i}$ - wartość atrybutu dla $i$-tego obiektu przed unitaryzacja.

$\mathrm{W}$ tabeli 1 . zestawiono 23 rodzaje wód mineralnych zajmujące najwyższe miejsca w rankingu.

Najwyższe miejsca w rankingu zajęły wody wysokozmineralizowane: Kissinger Bitterwasser Heilwasser (Niemcy) - 1. miejsce w rankingu, miernik syntetyczny $57,8 \%$, Hunyadi Janos (Węgry) - 2. miejsce w rankingu, miernik syntetyczny 49,8\%, Cigelka (Słowacja) - 3. miejsce w rankingu, miernik syntetyczny $44,5 \%$. Na rysunku 2. przedstawiono wartości składu chemicznego wymienionych wód mineralnych po unitaryzacji. Duży wpływ na miernik syntetyczny wody Hunyadi Janos (Węgry) miał anion siarczanowy oraz ogólna zawartość składników rozpuszczonych. W rankingu wody duże znaczenie miały również anion siarczanowy $\mathrm{w}$ przypadku wody Kissinger Bitterwasser Heil- 
wasser (Niemcy) oraz kation sodowy i anion wodorowęglanowy w przypadku wody Cigelka (Słowacja) (rys. 3.).

Tabela 1. Ranking wód mineralnych wybranych krajów Europy pod względem zawartości poszczególnych minerałów, opracowanie własne

\begin{tabular}{|c|c|c|c|c|c|c|c|c|c|c|c|}
\hline \multirow[b]{2}{*}{ Lp. } & \multirow[b]{2}{*}{$\begin{array}{l}\text { Nazwa wody } \\
\quad \text { (kraj) }\end{array}$} & \multirow{2}{*}{ 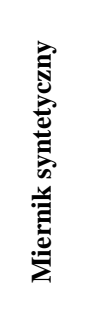 } & \multirow[b]{2}{*}{ 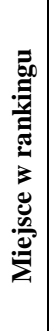 } & \multirow{2}{*}{ 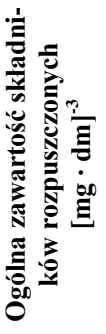 } & \multicolumn{4}{|c|}{ Kationy $\left[\mathrm{mg} \cdot \mathrm{dm}^{-3}\right]$} & \multicolumn{3}{|c|}{ Aniony $\left[\mathrm{mg} \cdot \mathrm{dm}^{-3}\right]$} \\
\hline & & & & & 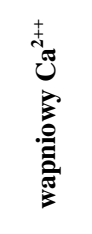 & 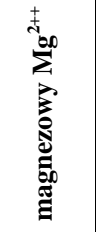 & 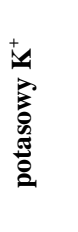 & 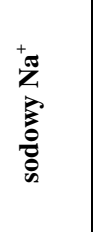 & 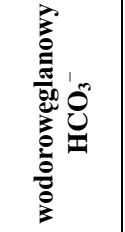 & 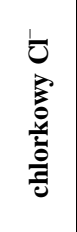 & 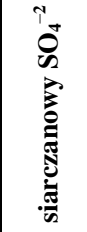 \\
\hline 1. & $\begin{array}{c}\text { Acqua Arve } \\
\text { (Włochy) }\end{array}$ & $14,5 \%$ & 11. & 3754 & 694 & 124 & 13 & 310 & 550 & 310 & 1918 \\
\hline 2. & $\begin{array}{c}\text { Acqua Regina } \\
\text { (Włochy) }\end{array}$ & $40,3 \%$ & 4. & 17295 & 657,3 & 119,16 & 129,5 & 5570 & 619,15 & 8792 & 1506 \\
\hline 3. & $\begin{array}{c}\text { Acqua Santa di } \\
\text { Chianciano } \\
\text { (Włochy) }\end{array}$ & $13,8 \%$ & 12. & 3398 & 714 & 172 & 6,1 & 40,5 & 829,6 & 18,7 & 1810 \\
\hline 4. & $\begin{array}{c}\text { Agua de Salenys } \\
\text { (Hiszpania) }\end{array}$ & $13,2 \%$ & 14. & 4231 & 651 & 119 & 70 & 145,4 & 2830 & 41,2 & 2,5 \\
\hline 5. & $\begin{array}{c}\text { Aqua Sara } \\
\text { (Rumunia) }\end{array}$ & $0,8 \%$ & 23. & 890 & 99,9 & 20,9 & 2,32 & 3,76 & 408,7 & 3,5 & 2 \\
\hline 6. & $\begin{array}{c}\text { Bad Mergenthe- } \\
\text { imer Karlsquelle } \\
\text { (Niemcy) }\end{array}$ & $38,6 \%$ & 6. & 18000 & 750 & 376 & 99,2 & 4670 & 1377 & 6100 & 3870,7 \\
\hline 7. & $\begin{array}{l}\text { Celvik Extra } \\
\text { (Bośnia } \\
\text { i Hercegowina) }\end{array}$ & $4,3 \%$ & 21. & 2925,91 & 144,28 & 145,8 & 23,46 & 460 & 1756,8 & 395,4 & 5 \\
\hline 8. & $\begin{array}{c}\text { Cigelka } \\
\text { (Słowacja) } \\
\end{array}$ & $44,5 \%$ & 3. & 29284,4 & 172,3 & 86,1 & 137 & 8127,9 & 216461,1 & 3761 & 4 \\
\hline 9. & $\begin{array}{c}\text { Donat } \\
\text { (Slowenia) }\end{array}$ & $18,5 \%$ & 9. & 16870 & 375 & 1060 & 17,1 & 1565 & 7790 & 66,6 & 2200 \\
\hline 10. & $\begin{array}{c}\text { Hunyadi Janos } \\
\text { (Węgry) }\end{array}$ & $49,8 \%$ & 2. & 37400 & 483 & 2930 & 40 & 4680 & 940 & 611 & 22170 \\
\hline 11. & $\begin{array}{c}\text { Hydroxydase } \\
\text { (Francja) }\end{array}$ & $13,5 \%$ & 13. & 9737 & 213,2 & 243 & 192,2 & 1945 & 6722,2 & 367 & 10,8 \\
\hline 12. & $\begin{array}{c}\text { Karlsquelle } \\
\text { Heilwasser } \\
\text { (Niemcy) } \\
\end{array}$ & $39,6 \%$ & 5. & 17121 & 782 & 389 & 113 & 4795 & 232 & 6382 & 3860 \\
\hline 13. & $\begin{array}{c}\text { Kissinger } \\
\text { Bitterwasser } \\
\text { Heilwasser } \\
\text { (Niemcy) }\end{array}$ & $\mathbf{5 7 , 8 \%}$ & 1. & 32156 & 539 & 4196 & 92 & 4690 & 256 & 3739 & 21634 \\
\hline 14. & $\begin{array}{c}\text { Mira } \\
\text { (Węgry) }\end{array}$ & $26,7 \%$ & 8. & 18200 & 230 & 496 & 34 & 4800 & 1226 & 2700 & 8060 \\
\hline 15. & $\begin{array}{c}\text { Pergoli } \\
\text { di Tabiano } \\
\text { (Włochy) }\end{array}$ & $12,5 \%$ & 16. & 2685 & 680 & 54 & 3,8 & 69 & 520 & 77 & 1455 \\
\hline
\end{tabular}


Tabela 1. cd.

\begin{tabular}{|c|c|c|c|c|c|c|c|c|c|c|c|}
\hline \multirow[b]{2}{*}{ Lp. } & \multirow[b]{2}{*}{$\begin{array}{l}\text { Nazwa wody } \\
\quad \text { (kraj) }\end{array}$} & \multirow{2}{*}{ 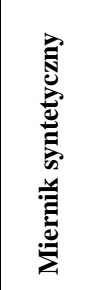 } & \multirow{2}{*}{ 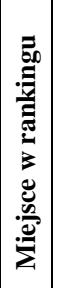 } & \multirow{2}{*}{ 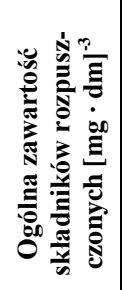 } & \multicolumn{4}{|c|}{ Kationy $\left[\mathrm{mg} \cdot \mathbf{d m}^{-3}\right]$} & \multicolumn{3}{|c|}{ Aniony $\left[\mathrm{mg} \cdot \mathbf{d m}^{-3}\right]$} \\
\hline & & & & & 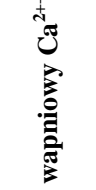 & 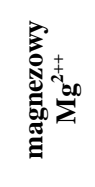 & 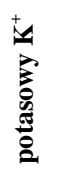 & 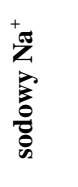 & 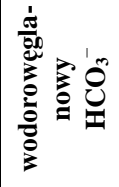 & 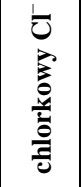 & 包 \\
\hline 16. & $\begin{array}{c}\text { Acqua Arve } \\
\text { (Włochy) }\end{array}$ & $14,5 \%$ & 11. & 3754 & 694 & 124 & 13 & 310 & 550 & 310 & 1918 \\
\hline 18. & $\begin{array}{c}\text { San Paolo } \\
\text { (Włochy) }\end{array}$ & $9,9 \%$ & 17. & 2255,2 & 306,3 & 77,4 & 254 & 250 & 1953 & 46,3 & 256 \\
\hline 19. & $\begin{array}{c}\text { Sulinka } \\
\text { (Słowacja) }\end{array}$ & $8,2 \%$ & 19. & 7481,7 & 271,6 & 344,3 & 43 & 110,3 & 5555 & 75,3 & 1,1 \\
\hline 20 & $\begin{array}{c}\text { Tuzlanski } \\
\text { Kiseljak } \\
\text { (Bośnia } \\
\text { i Hercegowina) } \\
\end{array}$ & $4,0 \%$ & 22. & 3398 & 56 & 650,3 & 11,44 & 186,2 & 3706 & 411,8 & 0,1 \\
\hline 21. & $\begin{array}{l}\text { Vesuvio } \\
\text { (Włochy) }\end{array}$ & $7,0 \%$ & 20. & 1773 & 78,4 & 142,9 & 300 & 172 & 952,8 & 369 & 220,2 \\
\hline 22. & $\begin{array}{c}\text { Wilhelmsquelle } \\
\text { Heilwasser } \\
\text { (Niemcy) }\end{array}$ & $15,2 \%$ & 10. & 4453 & 645 & 82,7 & 33 & 645 & 790 & 794 & 1820 \\
\hline 23. & $\begin{array}{c}\text { Zuber } \\
\text { (Polska) }\end{array}$ & $28,9 \%$ & 7. & 26924,78 & 132,02 & 331,32 & 320 & 6495 & 18549,47 & 975,0 & 49,51 \\
\hline
\end{tabular}

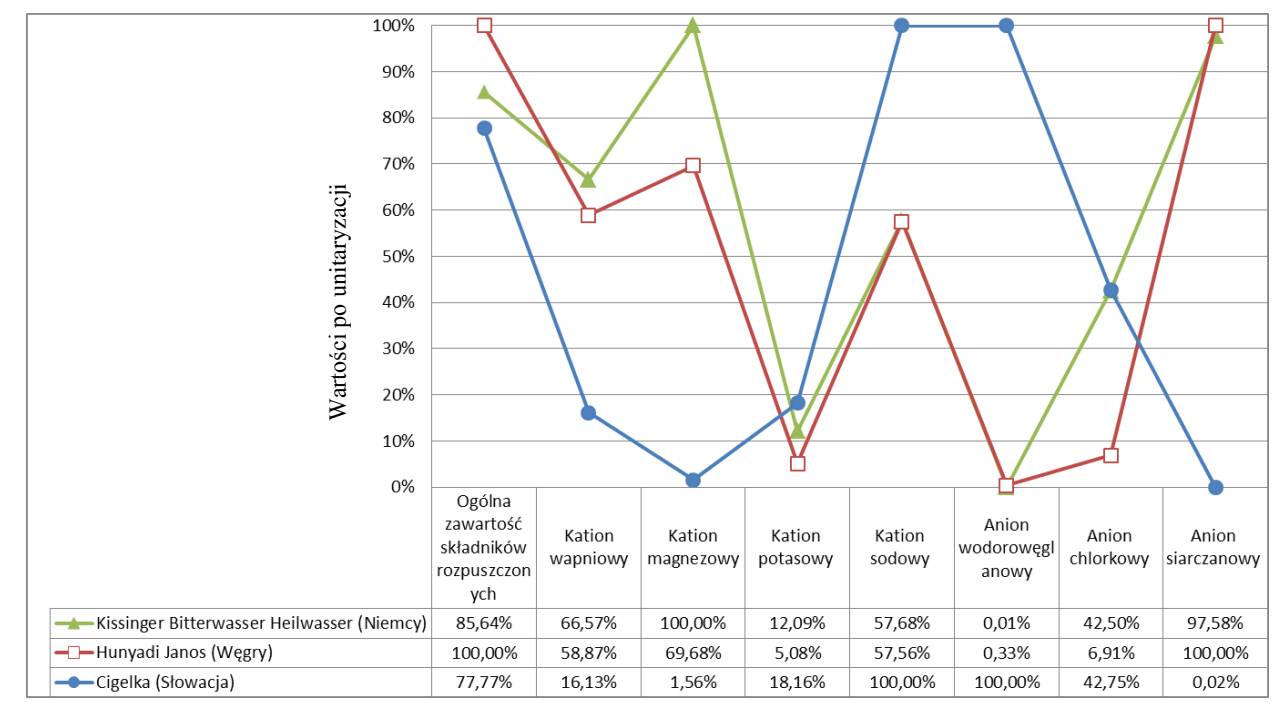

Rys. 3. Profile wód mineralnych powstałe w wyniku unitaryzacji 


\section{Wnioski}

1. Przedstawiona analiza wykazała, że na rynku europejskim występuje szeroki wybór wód mineralnych o zróżnicowanym składzie i różnym stopniu mineralizacji.

2. Z pośród 1030 przeanalizowanych wód ok. $60 \%$ stanowią wody niskozmineralizowane, ok. $16,2 \%$ - wody z zawartością wodorowęglanów wyższą od $600 \mathrm{mg} \cdot \mathrm{dm}^{-3}$, ok. $16,0 \%$ - wody zawierające wapń, ok. $14,5 \%$ - wody zawierające magnez, ok. 16,4\% - wody zawierające żelazo.

3. Porządkowanie liniowe pozwoliło wyodrębnić wody mineralne o największej zawartości składników mineralnych.

\section{Literatura}

[1] Global Bottled Water Report, Canadean 2007.

[2] Kryłowska-Kułas M.: Preferencje konsumentów związane ze spożywaniem wód butelkowanych, Journal of Elementology, no 12 (1), 2007, p. 55-62.

[3] Latour T.: Główne wskaźniki optymalnej pod względem zdrowotnym jakości wód naturalnych, Wydawn. Krajowej Izby Gospodarczej Przemysłu Rozlewniczego, Źródło, z. 4, 2005, s. 10-14.

[4] Rak J., Tchórzewska-Cieślak B., Pietrucha K.: Balneotechnika. Walory uzdrowiskowe, Oficyna Wydawnicza Politechniki Rzeszowskiej, Rzeszów 2011.

[5] Rak J., Pietrucha K.: O złożach i źródłach wód uzdrowiskowych. Technologia wody, Wydawnictwo Seidel-Przywecki, z. 2, 2010.

[6] Dyrektywa 2001/83/WE Parlamentu Europejskiego i Rady z dnia 6 listopada 2001 r. w sprawie wspólnotowego kodeksu odnoszącego się do produktów leczniczych stosowanych u ludzi.

[7] Dyrektywa 2009/54/WE Parlamentu Europejskiego i Rady z dnia 18 czerwca 2009 r. w sprawie wydobywania i wprowadzania do obrotu naturalnych wód mineralnych.

[8] Sobolewski M.: Przykłady zastosowań wybranych metod statystycznej analizy wielowymiarowej, Oficyna Wydawnicza Politechniki Rzeszowskiej, Rzeszów 2000 .

\section{ANALYSIS OF THE CHOSEN BOTTLED MINERAL WATERS COMPOSITION IN A EUROPEAN MARKET}

S u m m a ry

In the work the characteristics of bottled mineral waters composition being found in a European market were made. 1030 mineral waters were provided with analysis, from Germany $(9,4 \%$ of the total sum), of Spain (9,5\%), Italian (9,2\%), France $(9,2 \%)$, remaining $62,6 \%$ other states. Classification of tested waters according to legal documents being in force was obtained. Characteristics of 23 mineral waters of mineral according to the largest content and a linear organising hierarchization were also described including the combination of all mineral elements.

Keywords: bottled mineral waters, chemical composition, Europe

DOI: $10.7862 / \mathrm{rb} .2012 .6$ 